\title{
Chemical and mineral composition of furnace slags produced in the combustion process of hard coal
}

\author{
D. Smołka-Danielowska' ${ }^{1} \cdot$ M. Kądziołka-Gaweł ${ }^{2} \cdot$ T. Krzykawski $^{1}$
}

Received: 11 January 2018 / Revised: 16 July 2018 / Accepted: 15 November 2018 / Published online: 22 November 2018

(c) The Author(s) 2018

\begin{abstract}
Presented are the results of the examination of the chemical and mineral composition as well as iron compounds in furnace hearth slags coming into existence after the burning of hard coal. The samples of furnace hearth slags from heat and power plant and the hearths of the individual home furnaces fitted out with grate firings were compared. The examination methods like X-ray diffraction (XRD) with powder method, Mössbauer spectroscopy, scanning electron microscopy and ICP analysis were used. The main components of furnace hearth slags are $\mathrm{SiO}_{2}, \mathrm{Al}_{2} \mathrm{O}_{3}$ and $\mathrm{Fe}_{2} \mathrm{O}_{3}$. On the basis of the X-ray diffraction, it was found that the domination components of furnace hearth slags are mullite and quartz. Furnace hearth slags are different as for the content of the concentration of toxic elements $(\mathrm{Cd}, \mathrm{Cr}, \mathrm{Ni}, \mathrm{Tl}, \mathrm{Pb}, \mathrm{Zn}, \mathrm{As}, \mathrm{Ba}$ and $\mathrm{Cu})$ and $\mathrm{Fe}$.
\end{abstract}

Keywords Coal burning $\cdot$ Blast furnace slag $\cdot$ Mössbauer spectroscopy $\cdot$ Phase and chemical composition

\section{Introduction}

Production of electricity in Poland is based mainly on hard coal (about 70 million tons per year), and the side effect is a big amount of furnace hearth waste (fly ashes and slags) (GUS 2017).

In the Polish power industry in 2016, about 22 thousand tons of waste in total was produced (GUS, 2017). The volatile ashes produced from hard coal constituted 3.900 thousand tons, and almost 12 thousand tons were ash-slag mixtures from wet furnace hearth waste removal (Smarzewski and Barnat-Hunek 2015). The amount of produced solid waste depends on the amount of consumed coal and its quality, the effectiveness of the used dedusting equipment and the type and structure of the furnace hearth. The typical stoker-fired boilers in the power plants in Poland are fired with fine hard coal characterized with a great content of

Editorial responsibility: M. Abbaspour.

D. Smołka-Danielowska

danuta.smolka-danielowska@us.edu.pl

1 Faculty of Earth Science, University of Silesia, Będzińska 60, 41-200 Sosnowiec, Poland

2 Department of Nuclear Physics and Its Applications, University of Silesia, 75 Pułku Piechoty, 41-500 Chorzów, Poland volatile parts, no or low sintering ability. It is recommended that the calorific value of the coal being burned is in the range of 21 up to $23 \mathrm{MJ} / \mathrm{kg}$, ash content not exceeding $16 \%$, humidity up to $11 \%$, sinterability acc. to Roga from 7 up to 22 (www.ekozub.p1/2013).

The consumption of hard coal in individual home furnaces for the year 2016 amounted to approximately 11.5 million tons (GUS 2017). In 2016178 thousand tons of hard coal (GUS, 2017) was used in non-professional heatgenerating plants. (Coal is burned for the needs of heating homes.) It is assumed that about $0.4-0.5$ tons of furnace waste (ashes and slags) is produced from every $1 \mathrm{t}$ of hard coal. Due to the lack of reliable statistical data, it is hard to assess the quantity of waste produced in the hearths of individual home furnaces. In the chemical composition of furnace hearth slag, about $50 \%$ of silica $\mathrm{SiO}_{2}$ can be found and a considerable amount of aluminum oxide $\mathrm{Al}_{2} \mathrm{O}_{3}$ (over 23\%) (Freidin et al. 1995; Sales and De Souza 2009; Smarzewski and Barnat-Hunek 2015; Xuan et al. 2016; Qi et al. 2018). The content of iron is on the level of 5 up to $9 \%$. Few literature data on the slag mineral composition show that apart from glaze the furnace hearth slags contain mullite, quartz, anorthite, melilite, burned clay rock, magnetite and gypsum precipitation (Strzałkowska 2003, 2011; Kostakis 2011; Qi et al. 2018). The factor decisive for the hazard of slag for the environment is the possibility of washing out of harmful substances including trace elements (As, $\mathrm{Hg}, \mathrm{Tl}, \mathrm{Cr}, \mathrm{Ni}$, 
$\mathrm{Pb}, \mathrm{Cr}, \mathrm{Zn}$ ) that can penetrate into surface water and soil. Therefore, the determination of their physical and chemical properties, mainly their phase composition, is the subject of many studies of applied character. The iron-bearing minerals are major constituents of the coal mineral matter, and among them pyrite and its transformation products are responsible for many problems associated with coal utilization. During the burning process, the iron contained in coal (mainly in the form of sulfides) is being transformed into magnetic iron oxides (chiefly magnetite and maghemite) and it co-occurs with an amorphous substance (Magiera et al. 2009, 2010).

The objective of this study was to compare the chemical and mineral composition of furnace hearth slags produced in grate boilers in different temperature regimes. The substantial element of analyses is the use of the spectroscopy of the Mössbauer effect in the examination of iron in furnace slags. Identification of iron-bearing phases is important because it was suggested from in vitro studies that ferric iron in an aluminosilicate glass phase served as the source of bio-available iron from coal ash and that the process to make iron bio-available depended on ash particle size (Veranth et al. 2000a, b).

In practice, each particular type of slag is unique, which requires application of many different research techniques. That is why the following methods were applied: X-ray diffraction measurements (XRD), scanning electron microscopy and ICP analysis. Especially in the case where the sample is rich in iron-bearing phases, the application of routine analytical methods does not always lead to unambiguous results. Therefore, these results were correlated with the spectroscopic data, which was Mössbauer spectroscopy.

\section{Experiments}

\section{Slag samples}

Furnace hearth slag samples (S2, S4, S6, S7, S8) come from thermal power plant and individual home furnace hearth (S1, S3, S5, S9) located in Ruda Śląska (Silesia Province, Poland). The furnace hearth slags from thermal power plants were produced in the process of hard coal burning in the grate furnace (WR10 boiler) fitted out with the system of dedusting of flue gas of cyclone type. The temperature in the combustion chamber was about $850-900^{\circ} \mathrm{C}$. The slags from an individual home furnace hearth were brought into being after burning hard coal in a boiler with fire grate (burning temperature about $270-300^{\circ} \mathrm{C}$ ). The highest temperatures in the furnace hearth are in the zone of embers and in the zones of intensive aeration. All taken samples of furnace hearth slags were in the form of dark brown, glazed and porous lumps. Slug aggregates are created irrespective of coal type and burning technology. The decisive factors for producing slag are the nature of the mineral substance contained in coal, and low temperatures of softening, melting, and ash sintering, as well as high temperatures in the zone of embers (e.g., as a result of too intensive aeration of the fuel layer).

\section{Materials and methods}

The trace element analysis was performed by the Activation Laboratories Ltd (Canada, Ancaster). The analysis was performed on powdered samples using an inductively coupled plasma mass spectrometry (ICP-MS) and an inductively coupled plasma atomic emission spectrometry (ICP-AES) on BFS samples digested with $\mathrm{HNO}_{3}-\mathrm{HCl}$ at $95-100^{\circ} \mathrm{C}$ for $2 \mathrm{~h}$. One control and one blank sample were used in the analysis.

Analyses by means of Analytical Scanning Electron Microscopy (ASEM) were made by means of scanning electron microscope produced by PHILIPS XL 30 equipped with EDS attachment. The voltage was $15 \mathrm{kV}$ and bundle intensity $20 \mathrm{nA}$. Analyses were made in the Laboratory of Scanning Microscopy at the Faculty of Earth Sciences of the University of Silesia on the polished sections. Polished sections were prepared in such way that samples were sealed in epoxy resin and polished.

To identify mineral components of slags, X-ray diffractometry (XRD) was applied while Mössbauer spectroscopy was used to analyze iron compounds occurring in the samples.

Mössbauer spectroscopy was used to characterize various iron-bearing minerals in the investigated samples of slag and also investigate the oxidation state of $\mathrm{Fe}$ atoms in minerals. The ${ }^{57} \mathrm{Fe}$ Mössbauer spectra were recorded at room temperature with a constant acceleration spectrometer with ${ }^{57} \mathrm{Co} /$ $\mathrm{Rh}$ source (activity $\sim 15 \mathrm{mCi}$ ), a multichannel analyzer with 1024 channels and a linear arrangement of the ${ }^{57}$ Co source, absorber and detector. A gas proportional counter was used as a gamma-ray detector. A 2-mm plastic filter was placed in the beam to absorb the $\sim 6 \mathrm{keV} \mathrm{X}$-rays before they entered the detector. The $2 \mathrm{keV}$ escape peak and $14.4 \mathrm{keV}$ gammaray pulses were selected with a multichannel analyzer. A metallic iron foil $(\alpha-\mathrm{Fe})$ absorber was used for velocity and isomer shift calibration of the Mössbauer spectrometer. The line full width at half maximum (FWHM) for $\alpha$-Fe standard was $0.28 \mathrm{~mm} / \mathrm{s}$. No influence by the detector window on the spectrum was observed during the period of the measurements. The numerical analysis of the Mössbauer spectra was performed with the use of WMOSS program (Ion Prisecaru, WMOSS4 Mössbauer Spectral Analysis Software, 
2009-2016). The obtained spectra were fitted as a superposition of several doublets and sextets. The mineralogical analysis of the spectra was based on the Mössbauer Mineral Handbook (Stevens et al. 2005).

\section{Results and discussion}

\section{Chemical composition}

The basic chemical composition of the slag researched consists of (Table 1):

- aluminosilicates (designated as $\mathrm{Al}_{2} \mathrm{O}_{3}$ and $\mathrm{SiO}_{2}$ ) - in quantities of about $71 \%$ of the dry weight of the waste

- oxides of iron, calcium, magnesium and potassium-in quantities ranging from $17.06 \%$ to $21.90 \%$

- oxides of titanium, sodium and phosphorus-in quantities from 2.22 to $2.65 \%$

- losses of roasting (coal not burnt)—in quantities from 3.41 to $6.91 \%$ of the weight of the waste
The samples of slags from the heating plant are characterized by higher content of $\mathrm{Al}_{2} \mathrm{O}_{3}(22.13 \%)$. The average $\mathrm{Fe}_{2} \mathrm{O}_{3}$ content is at a similar level (10.95-10.89\%) in all samples of slag tested, regardless of the combustion process. Higher variation of $\mathrm{Fe}_{2} \mathrm{O}_{3}(4.45-16.41 \%)$ was observed in samples of slags from an individual home furnace (Table 1). The biggest differences relate to the share of oxides of calcium $(\mathrm{CaO})$ and magnesium $(\mathrm{MgO})$ and predominate in samples of slags from an individual home furnace. Their content is $1-1.5$ times higher compared to samples of furnace slags from heat-generating plants (Table 1). According to Vassilev and Vassileva (1996), the higher content of Ca and $\mathrm{Mg}$ in furnace wastes results from the fact that these elements originate from the decomposition of carbonates and sulfates. In addition, at lower combustion temperatures, the decomposition of coarse particles containing calcite is incomplete.

The obtained results of testing the mineral composition of furnace slags coincide with the results of Vassilev and Vassileva (1996) who studied Bulgarian coals and products of their combustion (including slags) in professional power

Table 1 Chemical composition and trace elements in furnace slag

\begin{tabular}{|c|c|c|c|c|c|c|c|c|c|c|c|}
\hline \multirow[t]{2}{*}{ Marked component } & \multicolumn{5}{|c|}{ Slag_individual domestic furnace } & \multicolumn{6}{|c|}{ Slag_-heating plant } \\
\hline & $\overline{\mathrm{S} 1}$ & S3 & S5 & S9 & Average & S2 & $\mathrm{S} 4$ & S6 & S7 & S8 & Average \\
\hline \multicolumn{12}{|c|}{ Content of basic component ( $\%)$} \\
\hline $\mathrm{SiO}_{2}$ & 44.62 & 56.24 & 56.75 & 58.16 & 53.94 & 50.12 & 52.63 & 50.62 & 52.81 & 41.81 & 49.60 \\
\hline $\mathrm{Al}_{2} \mathrm{O}_{3}$ & 20.81 & 12.62 & 10.37 & 26.73 & 17.63 & 23.16 & 26.44 & 18.56 & 19.31 & 23.17 & 22.13 \\
\hline $\mathrm{Fe}_{2} \mathrm{O}_{3}$ & 16.41 & 10.82 & 12.12 & 4.45 & 10.95 & 10.86 & 8.50 & 11.27 & 11.63 & 12.21 & 10.89 \\
\hline $\mathrm{CaO}$ & 6.12 & 6.51 & 7.66 & 2.87 & 5.79 & 2.93 & 2.26 & 2.88 & 2.36 & 2.42 & 2.57 \\
\hline $\mathrm{MgO}$ & 2.91 & 2.76 & 2.40 & 4.15 & 3.06 & 1.13 & 1.04 & 1.26 & 1.38 & 1.56 & 1.27 \\
\hline $\mathrm{TiO}_{2}$ & 0.94 & 0.86 & 0.85 & 0.45 & 0.78 & 1.01 & 1.13 & 1.08 & 1.11 & 1.06 & 1.08 \\
\hline $\mathrm{K}_{2} \mathrm{O}$ & 2.72 & 2.06 & 2.88 & 0.74 & 2.10 & 2.13 & 2.07 & 2.48 & 2.15 & 2.83 & 2.33 \\
\hline $\mathrm{Na}_{2} \mathrm{O}$ & 0.74 & 0.65 & 0.44 & 0.52 & 0.59 & 0.66 & 0.70 & 0.61 & 0.68 & 0.73 & 0.68 \\
\hline $\mathrm{P}_{2} \mathrm{O}_{5}$ & 0.94 & 0.99 & 0.86 & 0.61 & 0.85 & 0.90 & 0.89 & 0.91 & 0.86 & 0.88 & 0.89 \\
\hline Roasting losses & 2.16 & 5.47 & 4.89 & 1.11 & 3.41 & 5.72 & 3.23 & 7.57 & 6.64 & 11.41 & 6.91 \\
\hline Totality & 98.37 & 98.98 & 99.22 & 99.79 & 99.01 & 98.62 & 98.89 & 97.24 & 98.93 & 98.08 & 98.35 \\
\hline \multicolumn{12}{|c|}{ Trace elements (mg/kg; $\%$ ) } \\
\hline $\mathrm{Cd}$ & 0.7 & 1.3 & 1.5 & 1.7 & 1.3 & 0.5 & 0.7 & 0.6 & 0.7 & 0.6 & 0.6 \\
\hline $\mathrm{Cr}$ & 33 & 87 & 101 & 112 & 83.3 & 180 & 184 & 195 & 206 & 210 & 195 \\
\hline $\mathrm{Ni}$ & 20 & 99 & 135 & 143 & 99.3 & 64 & 73 & 69 & 70 & 73 & 69.8 \\
\hline $\mathrm{Tl}$ & 0.5 & 1.7 & 2.3 & 2.3 & 1.7 & 0.5 & 0.5 & 0.6 & 0.5 & 0.6 & 0.5 \\
\hline $\mathrm{Pb}$ & 48 & 66 & 78 & 99 & 72.7 & 16 & 18 & 21 & 21 & 23 & 19.8 \\
\hline $\mathrm{Zn}$ & 645 & 660 & 672 & 644 & 655.3 & 724 & 724 & 276 & 731 & 838 & 658.6 \\
\hline As & 12 & 18 & 26 & 24 & 20 & 0.5 & 1.3 & 2.2 & 2.1 & 2.5 & 6.6 \\
\hline $\mathrm{Ba}$ & 750 & 1125 & 1260 & 1168 & 1076 & 663 & 692 & 773 & 748 & 887 & 752.6 \\
\hline $\mathrm{Cu}$ & 77 & 96 & 117 & 98 & 97 & 77 & 78 & 80 & 79 & 89 & 80.6 \\
\hline $\mathrm{Fe}^{*}$ & 4.88 & 2.77 & 3.11 & 2.97 & 3.43 & 2.23 & 2.06 & 2.88 & 3.23 & 3.56 & 2.79 \\
\hline
\end{tabular}


plants. In their research they have shown that the source of solid phases in furnace wastes may be primary minerals (they do not participate in phase transformations), secondary minerals (formed in the combustion process) and minerals that are formed as a result of transport and storage of furnace waste. Reinmöller et al. (2015) observed the behavior of a mineral substance in hard coal, brown coal and in co-combustion with biomass in various temperatures and atmospheres (oxidizing and reducing one).

They have shown that at lower temperatures $\left(450 / 550^{\circ} \mathrm{C}\right)$ the number of mixtures of mineral phases from different groups calculated in the oxidizing atmosphere was higher and, on the contrary, lower in the range of high temperatures in the reducing atmosphere. Verma et al. (2015) analyzed the mineral components and trace elements contained in hard coal and its combustion products-in Indian fly ashes and bottom ashes. Fly ashes and bottom ashes originate from conventional furnaces, in which there is a higher combustion temperature compared to grate furnaces, but the results of their research indicate a high concentration of $\mathrm{Si}, \mathrm{Al}, \mathrm{Fe}$ and $\mathrm{Ca}$ in them.

These values are comparable to the results of the Polish literature studies for furnace hearth slags from the conventional power industry (Kurczabiński 2008) for that the determined concentrations of $\mathrm{SiO}_{2}$ and $\mathrm{Al}_{2} \mathrm{O}_{3}$ fall in the range of $49.31-50.1 \%$ and $20.62-23.7 \%$. In the tested samples of furnace hearth slags, $\mathrm{Fe}_{2} \mathrm{O}_{3}$ oxides occur on the similar level of content, irrespective of their origin (8.45-16.41\%). The literature data concerning the hearth slags from power plants indicate that the content of $\mathrm{Fe}_{2} \mathrm{O}_{3}$ in furnace hearth slags is in the range of from 4.94 up to $11.77 \%$ (Smarzewski and Barnat-Hunek 2015). Other oxides $\left(\mathrm{SO}_{3}, \mathrm{Na}_{2} \mathrm{O}, \mathrm{K}_{2} \mathrm{O}, \mathrm{TiO}_{2}\right.$, $\mathrm{P}_{2} \mathrm{O}_{5}$ ) occur in the amounts below $4 \%$ (by weight).

The roasting losses of the tested furnace hearth slags were from 1.11 up to $11.41 \%$. They are higher for the samples from heating plant $(6.91 \%$ on average). In grate furnaces it is very hard to obtain a slag with right parameters (below $5 \%$ of combustible parts). The parameters of the combustible substance that are decisive for the ignition process are the content of moisture and the content of ash (Smarzewski and Barnat-Hunek 2015).

The chemical features of the aggregate produced using furnace slags should meet the requirements specified in the standard PN-EN 12620+A1:2010 (aggregates for concrete). The roasting losses may not exceed $6 \%$ if the furnace slag is used as the only additive for the production of aggregates (the furnace slag aggregate may be used in construction industry after treatment) (Smarzewski and Barnat-Hunek 2015).

In slags there occur trace elements which constitute from 0.1 to $0.3 \%$ of the total weight of the waste. The share of these elements (including potentially toxic ones) in furnace wastes has been the purpose of research for several years due to their potential use, and as a result of their storageimpact on the environment (including living organisms). The hazard by slag for the environment is decided by the possibility of leaching harmful substances that can penetrate surface waters and cause their pollution (Kucowski et al. 1993; Kutchko and Kim 2006).

The results of determinations of trace elements: $\mathrm{Cd}$, $\mathrm{Tl}, \mathrm{Pb}, \mathrm{As}, \mathrm{Ba}$ and $\mathrm{Ni}$ in samples of furnace slags from an individual home furnace indicate their significant concentration in comparison with slags from the heat-generating plant. The average content of these elements is from 1.5 to 3.5 times higher than in samples of slag from heat-generating plants (Table 1). Slags from an individual home furnace are characterized by a higher concentration of $\mathrm{Pb}$ (average $-72.7 \mathrm{mg} / \mathrm{kg}$ ), Tl (average-1.7 mg/kg) and As (average $-20 \mathrm{mg} / \mathrm{kg}$ ) in relation to slags from heat-generating plants $(\mathrm{Pb}-19.8 \mathrm{mg} / \mathrm{kg}, \mathrm{Tl}-0.5 \mathrm{mg} / \mathrm{kg}$, As- $6.6 \mathrm{mg} / \mathrm{kg}$ ) (Table 1).The enrichment of furnace slags from an individual home furnace with trace elements follows according to the series: $\mathrm{Ba}>\mathrm{Zn}>\mathrm{Ni}>\mathrm{Cu}>\mathrm{Cr}>\mathrm{P}$ $\mathrm{b}>\mathrm{As}>\mathrm{Tl}>\mathrm{Cd}$; furnace slags from the heat-generating plants: $\mathrm{Ba}>\mathrm{Zn}>\mathrm{Cr}>\mathrm{Cu}>\mathrm{Ni}>\mathrm{Pb}>\mathrm{As}>\mathrm{Cd}>\mathrm{Tl}$. The content of iron in furnace slags varies, and it amounts from $2.06 \%$ up to $4.88 \%$. Higher values of iron concentration were found in the samples of slag from individual home furnaces. The obtained results concerning the concentrations of trace elements in furnace hearth slags are close to those published by few authors (Yao et al. 2004; Smarzewski and Barnat-Hunek 2015; Qi et al. 2018).

The higher content of As in the furnace slag samples from the individual home furnace confirms the thesis of Verma et al. (2015) that arsenic tends to form volatile compounds at relatively low temperatures, and that it easily separates between fly ash and residual waste.

An important element is the iron with which As is present in the association and hence the higher concentration of this element is in the furnace slag from an individual home furnace (Kaakinen et al. 1975). According to Yudowich and Ketris (2005), higher concentration of arsenic in furnace wastes may result from the positive correlation of As-S and As- $\mathrm{Fe}_{2} \mathrm{O}_{3}$, indicating pyrite as the carrier of As. Verma et al. (2015) state that both As and other trace elements $(\mathrm{Cd}, \mathrm{Ni}, \mathrm{Cu}, \mathrm{Pb}$ and $\mathrm{Zn})$ in furnace wastes coexist with $\mathrm{Mg}, \mathrm{Ca}$ and $\mathrm{P}$. This is confirmed by higher concentrations of $\mathrm{As}, \mathrm{Cd}, \mathrm{Ni}, \mathrm{Cu}$ and $\mathrm{Pb}$ in tested samples of furnace slags from an individual home furnace. The contents of $\mathrm{CaO}$ and $\mathrm{MgO}$ in these slags are $5.79 \%$ and $3.06 \%$, respectively. 
Chromium is the only element the average content of which is higher in the furnace slag samples from the heatgenerating plant $-195 \mathrm{mg} / \mathrm{kg}$. This is mainly due to the fact that $\mathrm{Cr}$ occurs in minerals of the type of aluminum silicates (the average content of $\mathrm{Al}_{2} \mathrm{O}_{3}$ in these samples is $22.13 \%$ and is higher compared to the furnace slags from an individual home furnace-17.63\%) (Table 1).

For more accurate determination of these relationships, it would be necessary to analyze the content of trace elements in the hard coal from which the slags were produced. This is impossible in the case of slags produced in the heat-generating plant, because it is based on hard coal originating from several mines owned by the Upper Silesian Coal Basin.

\section{Phase mineral composition}

No substantial quality differences in the mineral composition in furnace hearth slag samples using the XRD method were found. In those slags crystalline phases like mullite, quartz, calcite, gypsum, hematite, goethite, feldspar and spinels were found. Similar mineral components in furnace slags have been identified by, for example, Strzałkowska (2011) and Xiaobin et al. (2017). The mineral components in the samples of home furnace hearth slags differ as for their concentration. The samples of those furnace hearth slags contain also more unburned coal.

In the $\mathrm{S} 9$ sample from the furnace hearth slag, the content of cordierite $\left(\mathrm{Mg}_{2} \mathrm{Al}_{3}\left[\mathrm{AlSiO}_{5} \mathrm{O}_{18}\right]\right)$ was identified. This mineral probably was in hard coal, and low combustion temperature caused that it has not undergone thermal conversion. Hence, its presence in the sample from the furnace hearth slag produced in home furnaces. Using the Rietveld method, a high percentage of both feldspar (14.3\%) were determined in the S9 sample. Probably cordierite co-occurred with and/ or feldspar. In that sample the content of $\mathrm{SiO}_{2}, \mathrm{Al}_{2} \mathrm{O}_{3}$ and $\mathrm{MgO}$ was highest $(58.16 \%, 26.73 \%, 4.15 \%$, respectively) among all the tested samples taken from an individual home furnace hearth.

Mullite was identified in all the samples of furnace hearth slags taken from domestic furnace. Its concentration was 10.1 up to $60.2 \%$. Its content was lowest only in the S1 and S2 samples (10.1-10.9\%). Hematite was identified in all the samples of furnace hearth slags taken from an individual domestic furnace. Its concentration was 0.8 up to $2.8 \%$. Its content was lowest only in the S9 sample $(0.8 \%)$. Goethite was found in S1 and S3 samples, and its content was $3.7-1.2 \%$. Spinels were found in the $\mathrm{S} 3$ sample.

In the samples (S2, S4, S6, S7, S8) of the furnace hearth slags from a thermal power plant, the content of mullite is different. The highest concentration of mullite was found in the S6 sample (69.2\%) and S7 (81.9\%). In the S6 sample the content of corundum was assessed for $10.7 \%$, in the S2 and S4 samples for 5.6 up to $6.8 \%$, and in the samples S7 and $\mathrm{S} 8$ it was not identified at all. The highest content of quartz $(40.0 \%)$ was identified in the S2 sample. The concentration of quartz in other samples falls into the range of 5.3 up to $17.0 \%$. Other mineral components determined in the furnace hearth slags from a thermal power plant with the content below 5\% were cristobalite and calcite. From the minerals that contain iron, the presence of hematite was identified in the S2 sample (2.6\%), goethite (S2-1.1\% and S8-3.4\%), spinel (S4-2.4\% and S8-8.5\%) and melilite (akermanite/ gehlenite) (S8-7.9\%).

In the vast majority of furnace hearth slags being tested, gypsum was found that occurs in the amount from 1.7 up to $50.8 \%$. So, high differences in the quantitative composition can result from its content in the hard coal being burned.

The estimated participation of coal mater and amorphous substance in the investigated samples of slag amounted to 5-30 vol\%.

The structure of slags depends mainly on the type of coal burned and the combustion temperature in the power boilers. The morphology and qualitative analysis of the phase composition in furnace hearth samples were carried out with the use of scanning microscope fitted out with EDS analysis system. The results of these observations are presented in Fig. 1. The morphology of the tested aggregates of hearth slags is very similar. They create oval and spherical forms and are very porous. Morphologically, the furnace slag particles do not differ. They are oval and spherical spheres composed mainly of $\mathrm{Al}_{2} \mathrm{O}_{3}$. Some of them contain small amounts of carbon. The main mineral phases present in the tested samples of furnace hearth samples are quartz and aluminosilicates with the admixture of $\mathrm{Mg}, \mathrm{Ca}, \mathrm{K}, \mathrm{Na}$ and $\mathrm{Fe}$. Often in the pores of hearth slags, unburned matter and trace elements $(\mathrm{Pb}, \mathrm{Zn})$ were found. The glaze occurs most frequently in the form of spherical grains with diameters ranging from 100 to $1000 \mu \mathrm{m}$. According to Vassilev and Vassileva (1995), crystalline matter in the furnace slag accumulates in the pores or on the surface of the particles, which favors an increase in vitreous phases containing $\mathrm{Fe}^{2+}$. This is confirmed by research carried out by Mössbauer's spectroscopy, on the basis of which it is found that hematite is the main magnetic phase present in almost all the tested samples of furnace slags.

\section{Analysis using the Mössbauer effect}

By using ${ }^{57} \mathrm{Fe}$ Mössbauer spectroscopy, one can identify different iron compounds present in a solid mixture. The samples have paramagnetic as well as magnetic fractions 

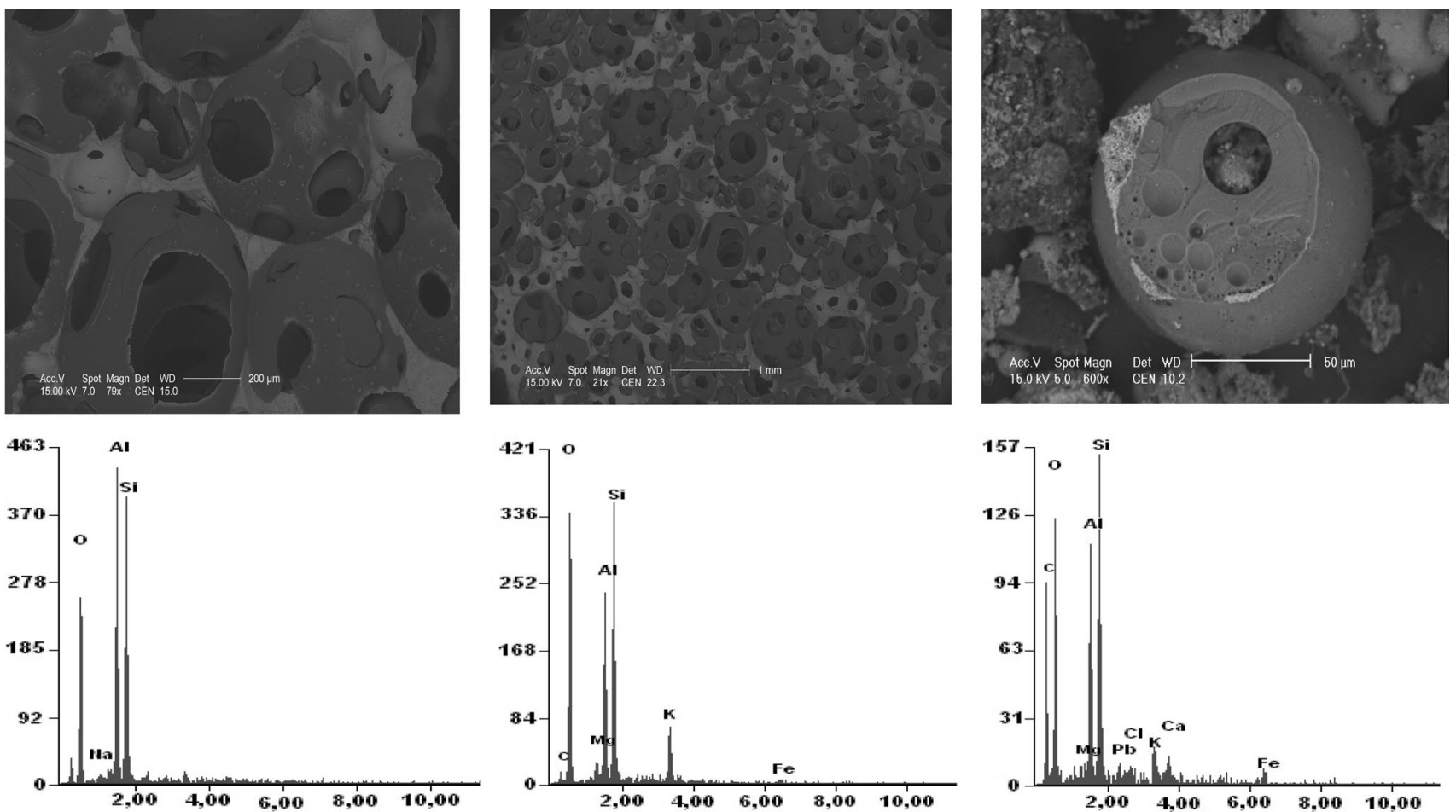

Fig. 1 SEM images and EDS spectra of typical spherical particles of slags after coal combustion (a, $\mathbf{c}$-individual domestic furnace; $\mathbf{b} —$ heating plant)

(except for samples S8 and S6). Figure 2 shows room temperature Mössbauer spectra together with fitted subspectra of the investigated slag samples. The site population has been calculated from the related area of the various subspectra with respect to the total area of spectra.

On each Mössbauer spectrum, dominated paramagnetic doublet D1 with an average isomer shift of about $0.20 \mathrm{~mm} / \mathrm{s}$ and quadruple splitting $0.37 \mathrm{~mm} / \mathrm{s}$ was assigned to $\mathrm{Fe}^{3+}$ ions. It might be assumed that this doublet corresponds to amorphous iron in glass (Oliweira et al. 2011; Haihan et al. 2012). Another ferric doublet visible on the Mössbauer spectra as $\mathrm{Mu} 1$ is connected with $\mathrm{Fe}^{3+}$ located in mullite. An average isomer shift of this doublet is equal $0.38 \mathrm{~mm} / \mathrm{s}$ and quadruple splitting $0.98 \mathrm{~mm} / \mathrm{s}$. With this mineral, ferrous doublet (Mu2) with isomer shift $1.15 \mathrm{~mm} / \mathrm{s}$ and quadruple splitting about $2.75 \mathrm{~mm} / \mathrm{s}$ is also related (Stevens et al. 2005). On the Mössbauer spectra, especially of furnace hearth slag samples, are visible the doublets D2 and D3 which are typical for $\mathrm{Fe}^{2+}$. The origin of this $\mathrm{Fe}^{2+}$ is unidentified. However, there are several reports on the investigation of the decomposition of coal allowing the claim to that these ions are located in silicate compounds (Srinivasachar et al. 1990; Veranth et al. 2000a, 2000b). An average isomer shift of
D2 doublet is equal $1.10 \mathrm{~mm} / \mathrm{s}$ and $1.14 \mathrm{~mm} / \mathrm{s}$ for D3. The value of quadruple splitting of D2 is $1.48 \mathrm{~mm} / \mathrm{s}$ and for D3 is $2.47 \mathrm{~mm} / \mathrm{s}$. In the samples S2, S3, S4 and S5, calcite was identified (Table 2).

Hematite (sextet $\mathrm{H}$ ) is the main magnetic phase present in almost all the investigated slag samples (except for samples S8 and S6). The hyperfine parameters observed for two another sextets correspond to tetrahedral and octahedral sites of iron in magnetite (sextets $\mathrm{M}$ ). These sextets are present on Mössbauer spectrum of S1, S3-S5 and S7 samples. In the samples S1, S5, S7 and S9, small amount of goethite (sextets G) was determinate. Sample S4 contains also a small part of some unidentified magnetic component represented by sextet (Mc) with hyperfine magnetic field $32.2 \mathrm{~T}$ and isomer shift $0.05 \mathrm{~mm} / \mathrm{s}$. This sextet can be connected with the small presence of $\alpha$-Fe.

In general, the Mössbauer spectroscopy study confirms results of XRD method. However, we should remember that the contribution of some minerals in the investigated samples is too small to be detected using the XRD method. The samples from individual home furnace hearth (S1, S3, S5, S9) and the samples (S2, S4, S6, S7, S8) of the furnace hearth slags from a thermal power plant are in general of similar 
Fig. 2 The room temperature Mössbauer spectra of the investigated samples. Fitted subspectra are visible on the spectrum; D1, D2, D3, Mu1, $\mathrm{Fe}^{3+}$ in mullite; $\mathrm{Mu} 2, \mathrm{Fe}^{2+}$ in mullite; $\mathrm{C}$, calcite; $\mathrm{H}$, hematite; M, magnetite; G, goethite; Mc, magnetic component
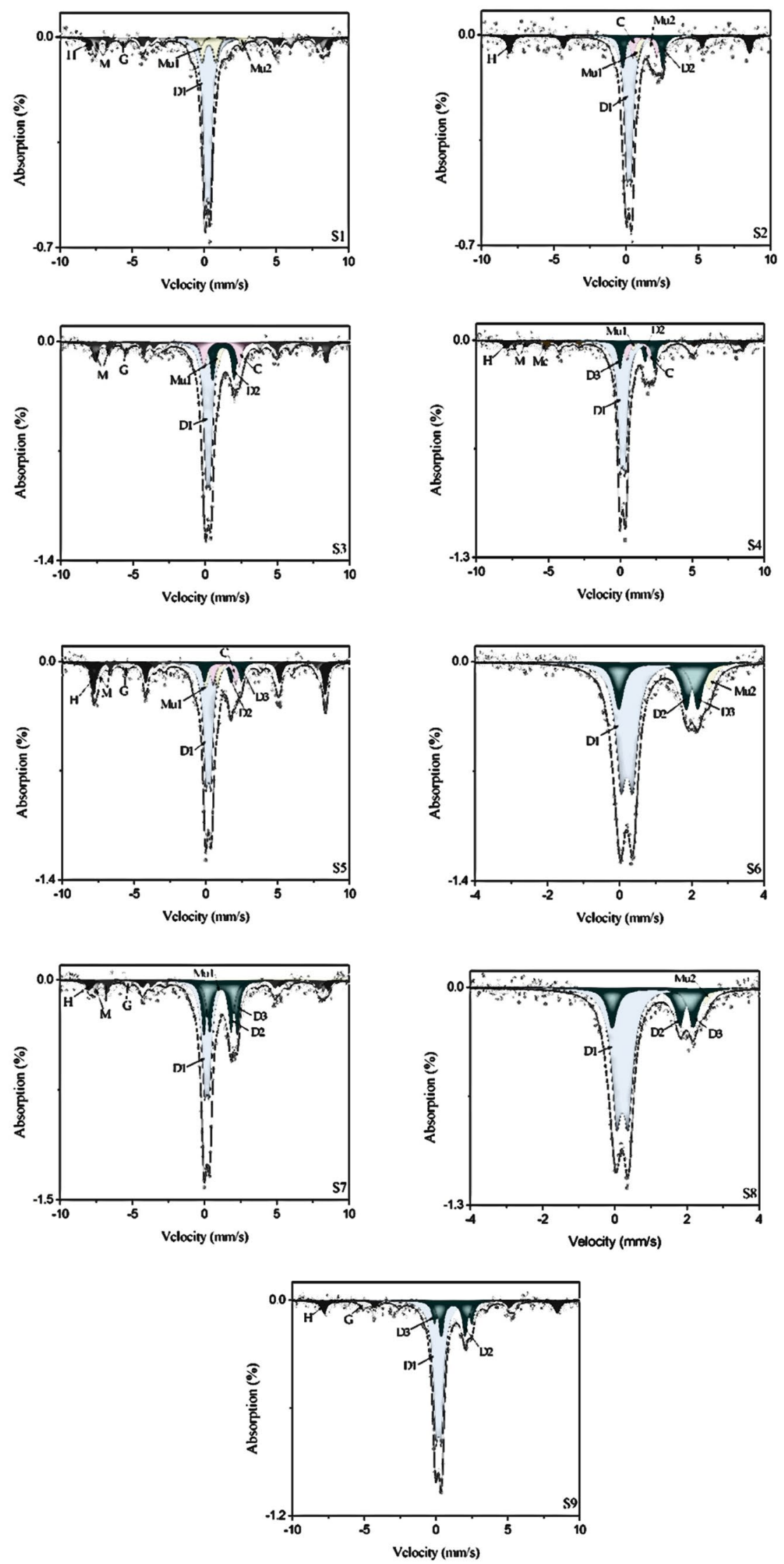
Table 2 Relative area of fitted Mössbauer subspectra for all the investigated slags

\begin{tabular}{|c|c|c|c|c|c|c|c|c|c|c|}
\hline \multirow[t]{2}{*}{ Sample } & \multicolumn{10}{|c|}{ Component } \\
\hline & $\overline{\mathrm{H}}$ & $\mathrm{M}$ & $\mathrm{G}$ & $\mathrm{Mc}$ & Mu1 & $\mathrm{Mu} 2$ & $\mathrm{C}$ & D1 & D2 & D3 \\
\hline $\mathrm{S} 1$ & 11 & 18 & 6 & - & 9 & 3 & - & 53 & - & - \\
\hline S3 & 21 & 8 & - & - & 9 & - & 13 & 40 & 9 & - \\
\hline S5 & 20 & 16 & 6 & - & 8 & - & 7 & 31 & 6 & 6 \\
\hline S9 & 9 & - & 7 & - & - & - & - & 54 & 17 & 13 \\
\hline $\mathrm{S} 2$ & 14 & - & - & - & 10 & 13 & 10 & 48 & 5 & - \\
\hline $\mathrm{S} 4$ & 7 & 9 & - & 6 & 4 & - & 8 & 45 & 9 & 12 \\
\hline S6 & - & - & - & - & - & 12 & - & 48 & 20 & 20 \\
\hline S7 & 7 & 16 & 4 & - & 4 & - & - & 32 & 18 & 19 \\
\hline S8 & - & - & - & - & - & 8 & - & 55 & 18 & 19 \\
\hline
\end{tabular}

D1, D2, D3, doublets; Mu1, $\mathrm{Fe}^{3+}$ in mullite; $\mathrm{Mu} 2, \mathrm{Fe}^{2+}$ in mullite; C, calcite; H, hematite; M, Magnetite; $\mathrm{G}$, goethite; Mc, magnetic component iron-bearing phase composition within the bounds of each group. All the investigated samples contain comparable amount of $\mathrm{Fe}^{3+}$ ions ( 50\%) connected with amorphous iron in glass. The rest of the iron in samples which come from individual domestic furnace exists mainly in the form of $\mathrm{Fe}^{2+}$ ions, while in the samples from heating plant contains a lot of $\mathrm{Fe}^{3+}$ located in magnetically ordered iron oxides. Abundance of particular phase in the sample can be different which is connected with long heat treatment period or heat treatment at higher temperature that leads to different iron oxide formations. The use of slags from different sources may be also one origin of these differences. Moreover, the presence of other metals as detected by ICP-MS study may affect differences in the magnetic and crystal structure of minerals in the investigated samples. According to Ram et al. (1995), Mössbauer spectroscopy is a powerful investigative tool for the accurate characterization of different iron-bearing minerals in coals and for studying the transformations of these minerals during coal combustion processes.

\section{Conclusion}

The paper sheds light on the physical nature of the chemical and mineral composition of furnace slags produced in the combustion process of hard coal. The techniques applied have proven to be useful in the investigation to the phase and elements concentration of such and similar genesis of wastes. The present paper may invoke attention in its own way to some sections of people concerned for environmental management and related issues.

The furnace hearth slags produced during the process of hard coal burning in grate furnaces, irrespective of the burning temperature, contain mainly mullite, quartz and gypsum. In the slags coming from the hearths of individual home furnaces, higher amounts of the minerals were found. Iron is present in the form of hematite and goethite. In those samples, higher concentrations of iron were also identified. Mössbauer measurements clearly identified the content of $\mathrm{Fe}$-bearing phases and the oxidation state of iron in the investigated samples. Additionally, the application of the Mössbauer spectroscopy provided a unique, clear and consistent characterization of the iron-bearing compounds and their relative abundances. The major iron-bearing of all the investigated slag samples was paramagnetic ferric iron in the amorphous phase and ferrous iron in silicates in samples from individual domestic furnace. Iron oxide like hematite was the main magnetic phase present in samples from heating plant. Existence of the sample of iron oxides plays an important role in process of adsorption of heavy metals which regulates the mobility of species in biota, soil or rivers. The concentration of trace elements $(\mathrm{Ba}, \mathrm{Cd}, \mathrm{Ni}, \mathrm{Tl}, \mathrm{Pb}$, $\mathrm{Zn}, \mathrm{As}$ ) and $\mathrm{Fe}$ in the slags from the hearths of individual home furnaces is higher when compared to the slags from the furnace hearths in thermal power plants. That is why the essential thing in the storage of those wastes should be the minimization of the concentration of the elements being analyzed. The practical use of furnace hearth slags from thermal power plants is possible provided that the examinations of the chemical and mineral composition are carried out periodically to guarantee their stabilization.

Acknowledgements The authors wish to thank all who assisted in conducting this work.

\section{Compliance with ethical standars}

Conflict of interest The authors declare that they have no conflicts of interest.

Open Access This article is distributed under the terms of the Creative Commons Attribution 4.0 International License (http://creat ivecommons.org/licenses/by/4.0/), which permits unrestricted use, 
distribution, and reproduction in any medium, provided you give appropriate credit to the original author(s) and the source, provide a link to the Creative Commons license, and indicate if changes were made.

\section{References}

Freidin K, Erell E (1995) Bricks made of coal fly-ash and slag, cured in the open air. Cement Concr Compos 17:289-300

GUS: Rocznik Statystyczny Rzeczpospolitej Polskiej (Statistical of the Republic of Poland) (2017). Consumption of fuels and energy carriers

Haihan Ch, Laskin A, Baltrusaitis J, Gorski Ch, Scherer M, Grassian V (2012) Coal fly ash as a source of iron in atmospheric dust. Environ Sci Technol 46:211-212

Kaakinen JW, Jorden RM, Lawasani MH, West RE (1975) Trace element behavior in coal-fired power plant. Environ Sci Technol 9:862-869

Kostakis G (2011) Mineralogical composition of boiler fouling and slagging deposits and their relation to fly ashes: the case of Kardia power plant. J Hazard Mater 185:1012-1018

Kucowski J, Laudyn D, Przekwas M (1993) Energetyka a ochrona środowiska. WNT, Warszawa

Kurczabiński L. (2008) Studium aktualnego stanu zasobów produkcji węgla W Polsce, głównie dla sektora ogrzewnictwa oraz prognoza do 2015 roku (materiały własne)

Kutchko BG, Kim AG (2006) Fly ash characterization by SEM-EDS. Fuel 85:2537-2544

Magiera T, Jabłońska M, Strzyszcz Z, Bzowska G (2009) Technogeniczne cząstki magnetyczne w pyłach atmosferycznych jako nośnik metali ciężkich. W: Inżynieria Środowiska pięć lat po wstąpieniu do Unii Europejskiej, Monografie Komitetu Inżynierii Środowiska PAN, Ozonek J., Pawłowska M. (red), vol 59, pp 115-126

Magiera T, Strzyszcz Z, Jabłońska M, Bzowska G (2010) Characterization of magnetic particulates in urban and industrial dusts [W] air pollution XVIII. In: Brebbia CA, Longhurst JWS (eds) Transactions on ecology and the environment, vol 136. WIT Press, Ashurst, pp 171-184

Oliweira M, Waanders F, Silva L, Jasper A, Sampaio C, McHabe D, Hatch R, Hower J (2011) A multi analytical approach to understand chemistry of Fe-minerals in fees coal and ashes. Coal Combust Gasif Products 3:51-62

PN-EN 12620+A1:2010 (2010) Aggregates for cocrete. ICS 91.100.15, 91.100.30. EN 12620:2002+A1:2008 [IDT], pp 1-56

Qi X, Song G, Song W, Yang S, Lu Q (2018) Combustion performance a slagging characteristics during co-combustion of Zhundong coal and sludge. J Energy Inst 91(3):397-410. https://doi. org/10.1016/j.joei.2017.02.002

Ram LC, Tripathi PSM, Mishra SP (1995) Mössbauer spectroscopic studies on the transformations of iron-bearing minerals during combustion of coals: correlation with fouling and slagging. Fuel Process Technol 42:47-60

Reinmöller M, Klinger M, Schreiner M, Gutte H (2015) Relationship between ash fusion temperatures of ashes from hard coal, brown coal, and biomass and mineral phases under different atmospheres: a combined FactSage ${ }^{\mathrm{TM}}$ computational and network theoretical approach. Fuel 151:118-123

Sales A, De Souza FR (2009) Concretes and mortars recycled with water treatment sludge and construction and demolition rubble. Constr Build Mater 23:2362-2370

Smarzewski P, Barnat-Hunek D (2015) Mechanical and microstructural properties of high performance concrete with furnace slag. Izolacje 10:26-32 
Srinivasachar S, Helble JJ, Boni AA (1990) Mineral behavior during coal combustion 1. Pyrite transformations. Prog Energy Combust Sci 16:281-292

Stevens JG, Khasanov AM, Miller JW, Pollak H, Li Z (2005) Mössbauer mineral handbook. Mössbauer Effect Data Center, Dalian, p 624

Strzałkowska E (2003) Charakterystyka mineralogiczno-geochemiczna popiołów i żużli powstałych ze spalania węgla na przykładzie Elektrowni Łaziska. Gospodarka Surowcami Mineralnymi 19(1):85

Strzałkowska E (2011) Charakterystyka właściwości fizykochemicznych i mineralogicznych wybranych ubocznych produktów spalania węgla. Wydawnictwo Politechniki Śląskiej, Gliwice

Vassilev SV, Vassileva ChG (1996) Mineralogy of combustion wastes from coal-fired power stations. Fuel Process Technol 47:261-280

Veranth JM, Smith KR, Hu AA, Lighty JS, Aust AE (2000a) Mobilization of iron from coal fly ash was dependent upon the particle size and source of coal: analysis of rates and mechanisms. Chem Res Toxicol 13:382-389
Veranth JM, Smith KR, Rohrbough JG, Huggins F, Hu AA, Lighty JS, Aust AE (2000b) b) Mössbauer spectroscopy indicates that iron is an aluminosilicate glass phase is the source of the bioavailable iron from coal fly ash. Chem Res Toxicol 13:161-164

Verma SK, Masto RE, Gautam Shalini, Choudhury DP, Ram LC, Maiti SK, Maity Sudip (2015) Investigations on PAHs and trace elements in coal and its combustion residues from a power plant. Fuel 162:138-147

www.ekozub.pl/2013

Xuan Weiwei, Zhang Jiansheng, Xia Dehong (2016) Crystallization characteristics of a coal slag and influence of crystals on the sharp increase of viscosity. Fuel 176:102-109

Yao H, Mkilaha ISN, Naruse I (2004) Screening of sorbents and capture of lead and cadmium compounds during sewage sludge combustion. Fuel 83:1001-1007

Yudovich YE, Ketris MP (2005) Arsenic in coal: a review. Int J Coal Geol 61:141-196 